\title{
Habits of the Home: Spatial Hegemony and the Structuration of House and Society in Brazil
}

This article examines the relation between spatial structure and social practice in a Brazilian fushing town. The sociospatial division of the Brazilian house into rooms with distinct social functions and role relationships helps to define the domestic practices of the family members and socializes them into a conception of social interaction that influences their economic and public practices outside the home. However, the hegemony of this domestic sociospatial structure is not autonomous, but rather stands in dynamic interaction with the public and economic dimensions of the household's reproduction in society. A comparison between canoe fishermen and boat fishermen demonstrates that their different involvement in the economic and public domains of the town affects their interpretation of the architectural structure of the house and differentiates their domestic practices.

For our house is our corner of the world. As has often been said, it is our first universe, a real cosmos in every sense of the word.

-Gaston Bachelard

By reason of his deep-rooted patriarchal formation, the Brazilian reflects the influence of the house both ecologically and economically. Nothing is more in the forefront of the poor man's thoughts than the idea of buying his shanty, or in the rich man's than, after making his fortune, to erect a fine mansion in full view of the street.

-Gilberto Freyre

Co WRITES FREYRE in hIS MONUMENTAL six-volume history of Brazilian patriarchal society (1963[1936]:xxviii). Half a century later, Roberto DaMatta writes in the same spirit:

In a relational universe like that of Brazil, there is nothing more clear than this multiple vision of the world, where one oscillates between at least three fundamental positions given by the house, by the street and by the afterworld. ... [Here] I am not only referring to a geographic or merely physical division of society, but to spheres of social action and meaning where an entire cosmology is empowered and constituted. [1987:162, my translation]

The centrality of the house in Brazilian society and its relation to other social domains are undeniable, but what is the nature of the implied relation between spatial structure and social practice?

Bourdieu's notion of habitus helps us clarify the complex relation of space and practice. Habitus is that array of commonsense, taken-for-granted social ways whose structuration of our practices often escapes us. Habitus simultaneously generates and is generated by social classifications reproduced in practice (Bourdieu 1977:72; 1984:170). These structural properties of practice "are both the medium and the outcome of the practices they recursively organize" in the process of structuration (Giddens 1984:25). Structures and 
classifications are simultaneously produced and reproduced, interiorized and exteriorized as the unintended consequences of both conscious and habitual pursuits (Certeau 1984:57; Giddens 1984:8-14, 1985:272-278; Sahlins 1985:ix; Touraine 1977:3-6). Bourdieu's conception of the production and reproduction of habitus in practice is comparable to Giddens's structural duality (1979:216-222), Sahlins's structure of conjuncture (1985:vii-xvii), Heidegger's Being-in-the-World (1962), Gramsci's cultural hegemony (1971), and Foucault's deep force relations (1978:92-97).

What these authors share is a conceptualization of practice as ways of coping, of attending to the everyday things, tasks, and demands of the social world. Culture exists foremost in what people do, not in what they think or say they do (Bourdieu 1977:2; Giddens 1979:39; Heidegger 1982:159; Ortner 1984:149-150). Habitual practices may eventually develop structural and schematic properties of which the actor who reproduces them is unaware: "The schemes of the habitus, the primary forms of classification, owe their specific efficacy to the fact that they function below the level of consciousness and language, beyond the reach of introspective scrutiny or control by the will" (Bourdieu 1984:466; see also Certeau 1984; Polanyi 1958). For the most part, people are not conscious of those practices that are closest to their cultural being. These practice theorists, therefore, search for the habitus in the mundane world of routine behavior, in spatial and material objectifications such as implements, works of art, dress, and urban designs, and especially in the house, which "through the intermediary of the divisions and hierarchies it sets up between things, persons, and practices ... continuously inculcates and reinforces the taxonomic principles underlying all the arbitrary provisions of this culture" (Bourdieu 1977:89; see Bourdieu 1973; Foucault 1977; Gilmore 1977; Richardson 1982).

Although Bourdieu's notion of habitus in terms of agency and structure seems especially appropriate for a study of architectural space or other material objectifications of social classification, I will demonstrate with an empirical analysis of domestic practice in Brazil that even a formalized habitus is more dynamic and less autonomous and hegemonic than Bourdieu suggests. Although the habitus may not become subject to discursive scrutiny, its reproduction in practice is always a contextual interpretation and therefore open to interactional diversity. The design of the typical house in the Brazilian town of Camurim, the ethnographic setting of this article, goes back more than two centuries. Yet the contemporary interpretation of this centuries-old architectural habitus in family life is mutually dependent on the economic and public activities of the household members outside the home. The spatial structure itself is hegemonic-in the sense that it reflects a dominant and pervasive ideological conception of family relations (see Gramsci 1971; Laclau and Mouffe 1985) - but its appropriation and social definition in domestic practice are not. It is this emphasis on the interpretation of the house in practice that makes my analysis distinct from other anthropological approaches to the study of domestic space, such as the ecological (Rapoport 1969, 1982), the structuralist (Cunningham 1973; Glassie 1975), the symbolic (Csikszentmihalyi and Rochberg-Halton 1981; Oliver 1987), or the proxemic analysis (Altman and Vinsel 1977; Hall 1969; Watson 1970). Instead, the practice approach used here has a much greater affinity with the humanistic approach in human geography (Ellen 1988; Pred 1981; Rowntree 1986; Tuan 1977) and the phenomenological approach in environmental psychology and architecture (Korosec-Serfaty 1985; Norberg-Schulz 1971, 1985, 1988; Seamon 1979, 1987).

The average house in Camurim has three main divisions: the front room, the kitchen, and the bedrooms. The kitchen is the area where the inhabitants reproduce themselves as a household. Household relations are expressed in material and emotional ways by sharing meals, affections, worries, and hardships. The parental bedroom is the area of conception, sexual intercourse, and physical recuperation. Here, in a very literal way, husband and wife shed their clothes and retreat within the intimacy of their bodies. The front room is the space in which the family relates to the outside world, receives guests, and presents itself to the community with the display of its most precious status symbols. 
This sociospatial organization of the house gains further significance in the society as a whole. The social relationships and boundaries of the kitchen, bedroom, and front room resemble those of the economic, domestic, and public domains. Society is reproduced through the economy, conceived in the home, and manipulated in the public sphere. The correspondence of these two levels of a hierarchical complex-house and society-is the result of an interpretive process in which social practice is understood in part from the perspective of the domestic world (Barnes 1985; Dumont 1979). Domestic practice provides a conception of social interaction that comes to figure outside the house (Bachelard 1969; Cooper 1974). For instance, the material obligations of a man to his family correspond to his contractual obligations at work, the conspicuous consumption in the front room resembles the competition for status in public, and the importance of sexual loyalty in the bedroom is related to the significance of the domestic world in the daily lives of the couple. Yet this interpretive process is not only directed from the house to society. At the same time, the men's economic and public positions, practices, and aspirations influence the interpretation and reproduction of the domestic world (Pratt 1981; Stallybras and White 1986). House and society constitute a dynamic complex in which changes in one are mirrored yet transformed in the other.

In this article, I will clarify the complex relation of space, habitus, and practice with an analysis of the domestic world of fishermen in the Brazilian town of Camurim. After a sketch of the ethnographic setting and a brief exposé of my method of data collection, I will demonstrate that the organization of society into economic, domestic, and public domains is not an analytic but an empirical division. Physical barriers and socially ambiguous spaces exist among the house, the sea, and the street that oblige fishermen to make phased transitions between the three domains of society. This analysis will be followed by a description of the principal interactional qualities that reinforce the differentiation of the societal and domestic domains in which Camurimenses operate. Finally, I will discuss the organization of the house and its correspondence to the three sociospatial domains of society. I will show how differences in economic status in combination with the sociospatial habitus give rise to different domestic practices, and how the boundaries erected between house and society are subverted by repeated transgressions.

\section{The Ethnographic Context}

Camurim is a coastal town of around 6,000 inhabitants located at the extreme south of the state of Bahia in northeast Brazil. The region was relatively isolated from the export economy from the 16th through the 19th century. Hostile Indian tribes prevented the colonization of the hinterland, and local peasants led a life of subsistence fishing and farming. Camurim only became fully incorporated into the Brazilian national economy during the rapid expansion of cocoa plantations in the 1930s (Filho 1976; Garcez and Freitas 1979), and after the completion of the coastal interstate highway BR-101 between Rio de Janeiro and Salvador in the 1960 s (see Figure 1). A strong regional elite of landowners, cattle ranchers, and planters emerged that carved up the virgin forests into sizable estates and created a lower class of plantation workers and day laborers. Fishing with small dugout canoes remained the only alternative available to poor Camurimenses who did not want to subject themselves to unrewarding plantation work. This relative autonomy became threatened in the late 1960 s by a regional development plan that stimulated the creation of a capital-intensive fishing industry. Government loans expanded the fishing fleet from three sailing vessels in 1970 to 32 motorboats in 1983, and large fish marketing companies began in 1975 to transport the growing output of fish from Camurim to the urban markets of Vitória and Rio de Janeiro.

However, this rapid economic development of the last two decades has not entirely replaced traditional fishing methods. There is a group of 50 canoe fishermen who still fish with gill nets and handlines in the shallow coastal waters of Camurim. Fishing trips last between two and twelve hours. Canoes are operated either by the owner or with the help 


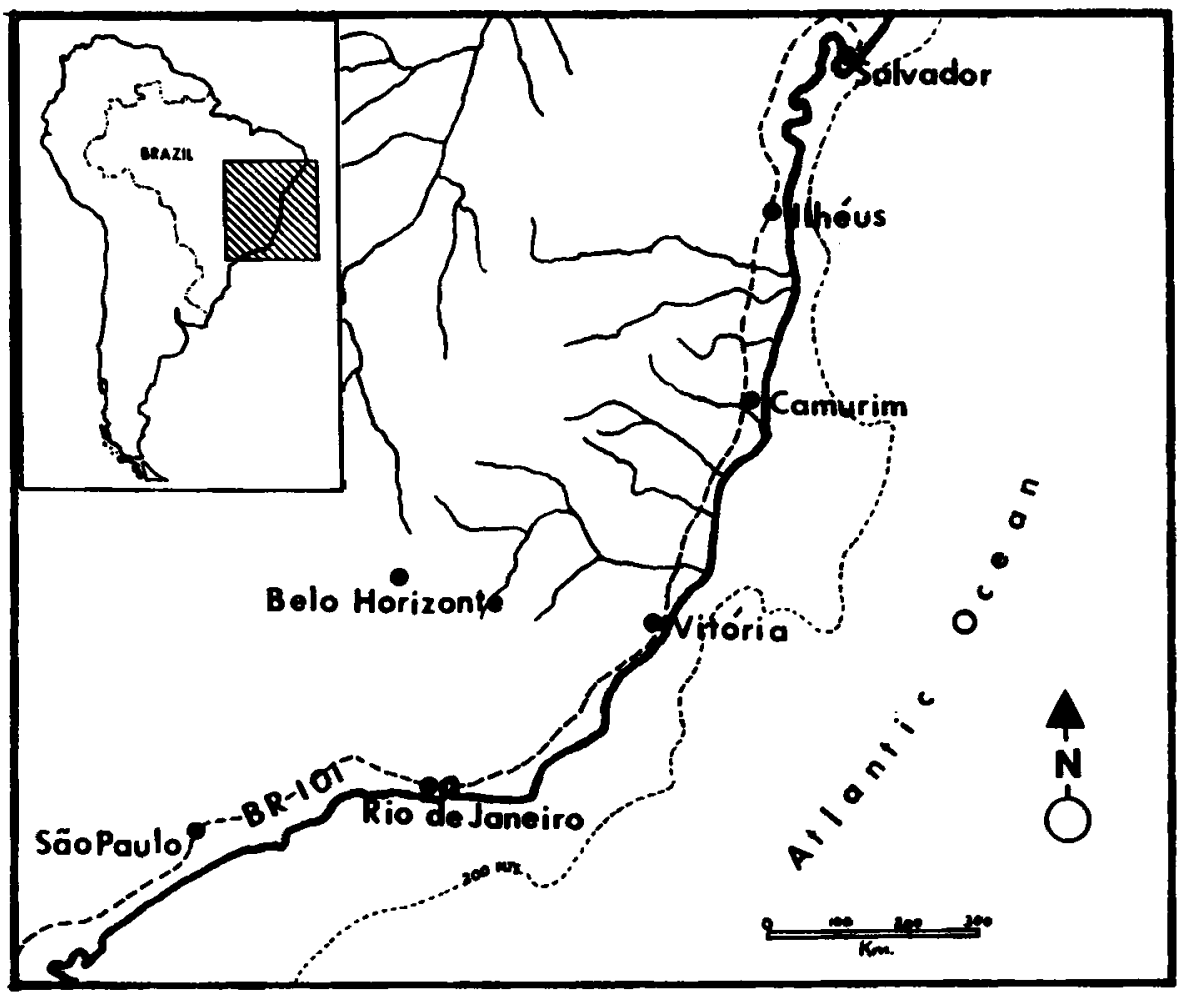

Figure 1

Geographical location of Camurim.

of a fishing partner. Only one man owns two canoes, while 33 fishermen own one canoe each. Taking into consideration that all canoe fishermen own fishing nets and the cost of a used dugout (\$30) does not exceed the earnings of one or two weeks, it is clear that canoe fishing is not likely to lead to rapid capital accumulation and social stratification. A concentration of economic power through a control of fish marketing is also improbable. Fish are sold by teenage street peddlers for a commission of $10 \%$ of the retail price. There are more than enough teenagers willing to sell fish, and the demand for fresh fish in Camurim often surpasses the daily production.

The boat fishing mode consists of 120 fishermen who operate 32 6-11 m motorboats. There is one owner of five boats, three men who own two boats each, and 21 men who each own one boat. The four-six man fishing crews remain up to ten days at sea. They exploit a vast area of coral reefs and sand banks between the coastal waters and the edge of the continental shelf. The 12 largest vessels fish exclusively with handlines, while the smaller boats alternate between the use of trawl nets, gill nets, and handlines. The high cost of even the smallest motorboat $(\$ 6,000)$ has resulted in a patronage system in which some former boat fishermen have succeeded in befriending local landowners to co-sign their bank loans. The growing monopolization of these social networks by the boat owners has hindered the upward mobility of the boat fishermen.

A pluriform fishery has emerged in which the earnings of the average canoe fisherman and boat fisherman are comparable but in which the economic prospects differ greatly (Robben 1989). Lower-class men can choose between a canoe fishing mode in which they control the means of production but that does not offer any opportunity for capital accumulation, and a stratified boat fishing mode that carries the promise of social mobility 
but in which the revenues are far more uncertain and subject to much larger fluctuations than in canoe fishing.

\section{Method}

An empirical study of domestic habitus is complicated by the epistemological dilemma that people may be so immersed in their social practices that straightforward questions about the routine of domestic interaction will either yield a decontextualized "outsider-oriented discourse" of formal rules and social recipes or "a discourse of familiarity [which] leaves unsaid all that goes without saying" (Bourdieu 1977:18, emphasis in original). Furthermore, there exists the danger that the ethnographer might impose his or her own cultural routine on the sociospatial patterning of another culture (Kent 1984). I tried to circumvent these methodological problems with several participant-observation research strategies, and by making a careful, culturally informed stratified sample of the population under study.

A thorough knowledge of Camurim's sociospatial divisions, its economic organization, the social composition and income distribution of the principal occupational groups, and the specific order in which people made material improvements on their homes (Drummond 1981) made it possible to identify the major socioeconomic ranks in Camurim and allowed me to relate this social scale to a corresponding range of house types according to their material quality and interior design. Frequent visits to the homes of five canoe fishermen, four boat owners, and sixteen boat fishermen, made in order to collect data on fishing revenues, gave me the opportunity to observe domestic life during the fieldwork period from August 1982 to December 1983. Occasional visits to over two dozen other households strongly suggested that the domestic interaction observed in the sample group was representative of the larger population. Methodological support for the representativeness of the principal sample of 25 out of a total of 175 fishing households has been provided by Romney, Weller, and Batchelder (1986:333). They established that a sample of even a half dozen informants may be very reliable when the cultural pattern under study-in this case the architectural structure of the houses of Camurim's lower class-has a considerable homogeneous distribution among the population. A comparison of floor plans showed that most houses in Camurim had been constructed according to a basic, traditional architectural design.

The diagram displayed below resembles best the interior organization of the typical house of a boat owner, boat fisherman, canoe fisherman, or any other lower-class person in Camurim. Architectural variations, such as the presence of a second front window or additional bedroom, the absence of a pantry, or the existence of a rear entrance instead of a side entrance, did not modify the basic sociospatial organization of the house. Only a half dozen absentee boat owners who claimed to have risen to the status of the local elite escaped the strictures of traditional housing by emulating the architecture of the newly built residences of planters, landowners, and tourists.

Instead of trying to isolate crucial features of domestic interaction through systematic proxemic notations, such as those developed by Hall (1974), a conscious choice was made for a less intrusive situational analysis (Patterson 1974) that concentrated on socialization practices and transgressions of domestic conventions. Parents used proverbs, sayings, admonishments, assertions, and maxims to impress on their children certain patterns of behavior that were already represented in the house in nonverbal ways through partitions between rooms, locks on doors, shutters on windows, and the arrangement of furniture, and, most important, through the social practices of other family members (see Bourdieu 1977:87-95; Certeau 1984:18-21; Polanyi 1958:27-65). Another important entry into domestic habitus was provided by recurring violations of domestic routines evoked either by marital strife, fights, drunkenness and illness or brought about by outsiders (tourists, traveling salesmen and preachers, health workers, the ethnographer), and social superiors (boat owners, the clergy, politicians, physicians, landowners). Both 
the discursive expressions in socialization and the social reactions to situations of conflict, intrusion, and domination delineated a realm of domestic habitus that could then be compared systematically among different types of households through participant-observation. The present analysis of domestic habitus in Camurim does not reflect the entire variation observed (see Robben 1989), ignores the homes of boat owners, and steps over the subtle differences between canoe owners and canoe fishermen, but focuses on the most salient contrasts and similarities between the households of boat fishermen and canoe fishermen living in virtually identical architectural spaces.

\section{The Transition Between Societal Domains}

\section{House and Street}

According to DaMatta and Freyre, the opposition between the house and the street is a basic feature of Brazilian culture that dichotomizes society into different social domains based on distinct interactional, ideological, hierarchical, and structural premises. They have defined the street as a public domain of hierarchical relationships with individuals and social classes engaged in a never-ending struggle for supremacy and power. The house, on the other hand, is a domestic domain of members related by blood and marriage with precise rights and obligations organized along age and gender (DaMatta 1981:70-74, 1987:39-54; Freyre 1961:30-66). This differentiation is of course not unique to Brazilian culture. A similar opposition can be found in ancient Greek and Hebrew and contemporary Islamic and Mediterranean cultures, with their progressions of parallel social categories such as public and private, inside and outside, modesty and display, honor and shame, loyalty and betrayal (Abu-Lughod 1986; Antoun 1968; Arendt 1958:22-78; Benn and Gaus 1983; Moore 1984; Nelson 1974; Peristiany 1965).

Given the strong opposition between the house and the street, people have created social, physical, and symbolic barriers to prevent their different qualities from mixing uncontrollably. The street is seen as polluted, as the source of evil, as a place of danger and conflict that may harm the members of the household if its bad influences are allowed to penetrate. Physical markers, thresholds, and ambiguous spaces are erected that serve to transform people symbolically during their transition from one social domain to another (Brown 1987; Taylor and Brower 1985; Van Gennep 1960:15-25).

The people of Camurim make sure to wipe their feet on the decorated doormat that rests on the doorstep when they enter a house as a symbolic gesture that they bring no evil to the house. A doormat is conspicuously absent at the rear entrance, where dirt and sand are constantly carried into the house. It is in the backyard that the domestic refuse is collected and via the side entrance (passeio) dumped into the street. The house is never swept from the back towards the front because people are afraid that otherwise the happiness of the house will be thrown out with the dirt (Cascudo 1954:161-162).

The sidewalk is a principal transitional space between the public and the domestic domain. It may either be part of the street or incorporated into the house. When the men are at sea, the women like to rest on large mats of plaited straw extended on the sidewalk. In Camurim, as in other parts of Brazil (DaMatta 1981:74), men sometimes place chairs on the sidewalk after a day's work to chat with neighbors and passersby. The sidewalk is clearly not for walking. Pedestrians walk on the street, and will only step on the sidewalk when they intend to visit the adjoining house.

\section{House and Sea}

As important as the opposition between the house and the street may be in Brazilian culture, the fishermen of Camurim distinguish between the house, the street, and the sea (a casa, a rua e o mar). The street must not be confounded with the working place. The economic domain has a strictly organized division of labor with well-defined statuses, chains of command, and distribution patterns. The street, on the other hand, is a volatile social universe in which the social divisions of the community become visible and indi- 
viduals compete for prestige, power, resources, and relationships. The social and symbolic boundaries among the three domains can be deduced from a time-spatial or daypath analysis of the different ways in which boat fishermen and canoe fishermen pass among the house, the street, and the sea (see Carlstein 1982:38-64; Mårtensson 1979:70101; Pred 1981; Shapcott and Steadman 1978).

The degree of participation in the three domains varies between the boat fishermen and canoe fishermen of Camurim. For boat fishermen, the public life of the street is paramount to that of the house. In public they can display prestige, obtain influence, and meet people who can advance their social and economic careers. Boat fishermen manifest their public status in bars, dance halls, and nightclubs. Canoe fishermen, instead, are ranked by their peers according to the quality of life and standard of living of their household. Their disengagement from the manipulation, intrigues, and power play of public life prevents public judgment from inserting itself between the domestic and the economic world of the canoe fishermen, as is reflected in their transition between the sea and the house.

Canoe fishermen never leave the house through its front door when they go to sea at sunrise but instead take the narrow passage that connects the sidewalk with the backyard. It is not just their concern for dirtying the house with the fishing gear that makes canoe fishermen take the side entrance-a bicycle, for instance, that has collected the mud and grime off the streets is wheeled freely through the house and kept in the front room-but rather the symbolic separation of the house and the sea that is at stake here. The bicycle is a prestige object used in the public domain that expresses the social status of its owner. The front door is used when the person enters the public domain, the side entrance when it concerns work.

The backyard is an intermediate space where activities are performed that come close to being classified as polluting. The members of the household use a corner of the backyard farthest away from the house as an open latrine, while the opposite corner serves as a bathing area screened off with a fence of plaited palm leaves. Upon their return ashore after a day's fishing, the canoe fishermen enter through the side passageway, wash themselves in the backyard, change their working clothes, and leave the house through the front door.

\section{Sea and Street}

Boat fishermen also enter and leave the house via the side passageway when they come from or go to sea, but their transition is more elaborate. When the men go fishing they go first to a bar to discuss the boat's supplies. They have to leave their public statuses behind, forget about the problems at home, and assume the responsibilities and attitudes of the labor relations aboard ship.

Once the boat returns to shore after a handlining trip, the individual catch of each fisherman is weighed separately, the fish are loaded into a refrigeration truck and transported to the urban centers of the south, and the crew departs for a nearby bar to settle the accounts. In the bar, the public status of boat owners and boat fishermen is redefined before they enter the community. The distribution of revenues indicates whether the economic statuses of persons have improved, deteriorated, or remained stable. The catch division is of course seldom so dramatic that it will move a person from one social status to another, but the outcome is significant enough to guide the fishermen's behavior and interaction during the days of leisure ashore.

The bar is also the place where boat fishermen overcome the abrupt change from a total to an open institution. Beer and rum flow freely as the exchange of drinks assuages brittle labor relations and helps to smooth out conflicts (Aubert 1965; Johnson 1979; Nolan 1976). When the revenues have been paid, the men shed their common identity as "seamen" (homens do mar) and emphasize their ranking and social differentiation. They have completed the transition from an imposed and at times tense association at sea to a desired dissociation ashore. Canoe fishermen, instead, go directly home after arriving at 
the beach. Their fishing trips are short, the street peddlers pay them at home, and their public status is defined through the domestic sphere. The indicators of public status are found at home, not in the street.

The spatial and material demarcations of the sea, the house, and the street, the existence of transitional spaces between them, and the systematic trajectories of fishermen as they pass from one sphere to another accentuate and establish clear boundaries for the three principal sociospatial domains of Camurim. By taking certain routes and avoiding others, the boat fishermen and canoe fishermen express their preference for different social transitions and status transformations. The house is the pivotal domain for the canoe fishermen, both in the sense of connecting the other two spheres and as the focus of their lives, while the public domain occupies that position for the boat fishermen. A close examination of the interaction in these three societal spheres is therefore needed to understand how their different quality and the different involvement of boat fishermen and canoe fishermen in them affect their domestic practices.

\section{Social Interaction at Work, at Home, and in Public}

Camurimenses characterize the quality of their social relations with the terms obrigação, consideração, and média. Obrigação (obligation) refers to the mutual expectations of two parties with respect to the reciprocal content of their social relationship. Consideração (consideration) refers to the anticipation of another person's needs without however experiencing their fulfillment as a duty or obligation. Unlike love, which is regarded in Camurim as a purely physical attraction, consideration is an expression in deed and gesture of personal affection, esteem, and respect between two persons. Acts of consideration are often embellishments of social relationships that may exceed the obligatory expectations and enhance their reciprocal quality with affection.

The existence of mutual obligation and consideration implies an enduring social relationship marked by a history of successful interaction that infuses the relation with reliability and trust. Despite the long-term standing of social relations, they may go through emotional ups and downs. The untranslatable term média is used by the people of Camurim to describe the relation of two persons at a particular moment. Média is a sort of emotional barometer that evaluates the mood and temperament of actors in their everyday interaction. In this sense, the média is a short-term indicator of a dyadic relation that is already based on obligation or consideration. However, the média is not only a complementary aspect but may also be a unique quality of reciprocal relations. People who have recently made each other's acquaintance may develop a média. They have a personal interest in each other that does not manifest itself in a substantive exchange but that still goes beyond the formal niceties of mere amity.

Each societal domain can be characterized by a distinct yet ambiguous combination of obligation, consideration, and média. Obligation predominates in the economic domain. Consideration is the prevalent quality of domestic relations, and média characterizes the public sphere. Although the quality of the social interaction in each societal domain can be generalized in this way, contextual ambiguities and classificatory disagreements about social relations are major sources of conflict. Power differences may allow one person or group to manipulate the reciprocal relation to its own advantage.

Economic relations are contractual relations. Fishermen agree to perform certain broadly defined productive tasks in exchange for a share of the catch. They perform the work assigned to them without anybody expecting them to carry out their activities with consideration. Still, crew members who spend many hours at sea under life-threatening conditions may in time develop mutual consideration. They will awaken each other when the fish are biting, decide together about the destination of their fishing trip, and help a colleague who has large medical bills because of a sick family member. The real threat to these voluntary acts of consideration is that they may be interpreted as obligations. Boat owners have the tendency to relegate a growing number of tasks to the fishermen (loading 
and unloading the vessel, cleaning the boat, making repairs), while presenting their own obligations as acts of consideration (giving fish for home consumption, lending social assistance, providing salary advances). In this way, acts of consideration that have been reclassified as obligations evade their reciprocation with equally valuable favors.

Economic relationships among canoe fishermen are also contractual but are complicated by their organization into corporate groups. Five groups of canoe fishermen control parts of the beach and the adjoining coastal fishing grounds. The members of each group also live in the same neighborhood, are organized around a kindred-based core, redistribute fish to unsuccessful corporate members, change the customary catch division to accommodate the needs of the crew members, give assistance to ill colleagues, and share many leisure activities together. Corporate members have a social solidarity and intimacy ashore that often imbues their relations with consideration. Yet this consideration is always measured with the yardstick of obligation. The close companionship between two canoe fishermen will inevitably dissolve if one does not carry out his productive tasks properly.

The concept of média is most commonly used to describe relations in public. Public relationships are loose, voluntary alliances that may easily shift into new configurations when more profitable relations can be found. Camurim's turbulent history shows many instances in which people suddenly moved from one political party to another and denounced their former comrades-in-arms as the reshuffling of national forces of power offered new political opportunities (Robben 1988a). Public relationships are not only restricted to political ties and patronage but include drinking friendships, credit arrangements, neighborhood ties, preferential treatment from public officials, and information networks among fishermen. All these voluntary social relations share an ephemeral and instantaneous quality.

Most public relationships can be broken off in an instant, and even economic relations may be replaced with relative ease, but domestic relations cannot be dissolved without serious emotional and social consequences. Domestic relations are multi-stranded relations, a complexity that is concretized in the spatial habitus. The domestic relations are imbued with consideration but, in addition, each social division in the house adds a different combination of obligation and média.

Men and women in Camurim believe that the love expressed during romantic courtship must be demonstrated in marriage through the fulfillment of conjugal obligations. This contractual element is especially apparent in the kitchen. A fishermen is expected to support the household financially, while his wife is supposed to bear children and take care of all the chores around the house. If the marital relation is filled with affection then husband and wife will not experience these expectations as obligations but will fulfill them out of consideration. Yet their material fulfillment is more essential than their emotional intent. Consideration is far more important in the bedroom. Sexual intimacy is sometimes felt as an obligation or temporarily damaged by a low média, but consideration is its principal quality. The purchase of a television set or a couch for the front room can be an expression of consideration, as is most often the case among canoe fishermen, but it also serves a clear public function. A luxury item is a status symbol, bought to enhance one's public prestige.

The organization of space into three sociospatial, societal domains and the three principal qualities of social interaction that characterize social relations in Camurim come together in the most intricate fashion in the house. The houses of the boat fishermen and canoe fishermen have virtually identical spatial structures and are very similar in architectural design, and the rooms are often occupied with the same objects. How do the fishermen come to grips with this spatial habitus if they do not give the same importance to the domestic world? How do the fishermen interpret the spatial organization of the house in their domestic practices? How does their different involvement in the household influence the relation with their family? And, finally, under what circumstances do the economic and public domains of society intrude upon the domestic world? 


\section{Social and Spatial Organization of the House}

With the exception of some 19th-century mansions and the large, modern residences constructed by tourists and rich townspeople, most houses in Camurim have a front room, two bedrooms, a kitchen, a pantry, and a backyard. The houses are generally 5-6 $\mathrm{m}$ wide and 8-10 $\mathrm{m}$ long, and have Dutch doors and one or two windows at the front and at the back (Figure 2).

This architectural design dates back to explicit instructions sent by the Portuguese Crown in 1755 to the authorities of Camurim:

every house of every village must have a front of 50 palmos $[11 \mathrm{~m}]$, a depth of 35 palmos $[7.7 \mathrm{~m}]$, be composed of a front room with a door and two windows toward the street, a bedroom for the parents, another one for the children, a pantry and a kitchen, and a backyard that must be 80 palmos $[17.6 \mathrm{~m}]$ long and 50 palmos $[11 \mathrm{~m}]$ wide, corresponding to the confines of the house. All houses must have the same front, height, doors, and windows. . [ [Revista Trimensal 1896:537; my translation].

This letter is remarkable evidence of a conscious effort to institutionalize into colonial society a sociospatial organization of the house that had only just emerged among the European nobility and middle class. The division of the house into functionally differentiated rooms took place in the first half of the 18th century. Before, people lived in general-purpose rooms in which they slept, ate, and worked (Ariès 1962:391-400; Elias 1978:160-168; Ranum 1986:219-232; Rybczynski 1986).

Poor townspeople and many fishermen live in wooden or wattle and daub houses with tile roofs, so characteristic of northeast Brazil (Freyre 1937; Pierson 1951:42-47). All other houses are made of brick. The homogeneous division of the house into three areas and the proscriptions that surround their use reinforce a domestic habitus. This habitus, nonetheless, has to be produced and reproduced continuously in everyday practice and, therefore, provides a clearing for reinterpretation and cultural change.

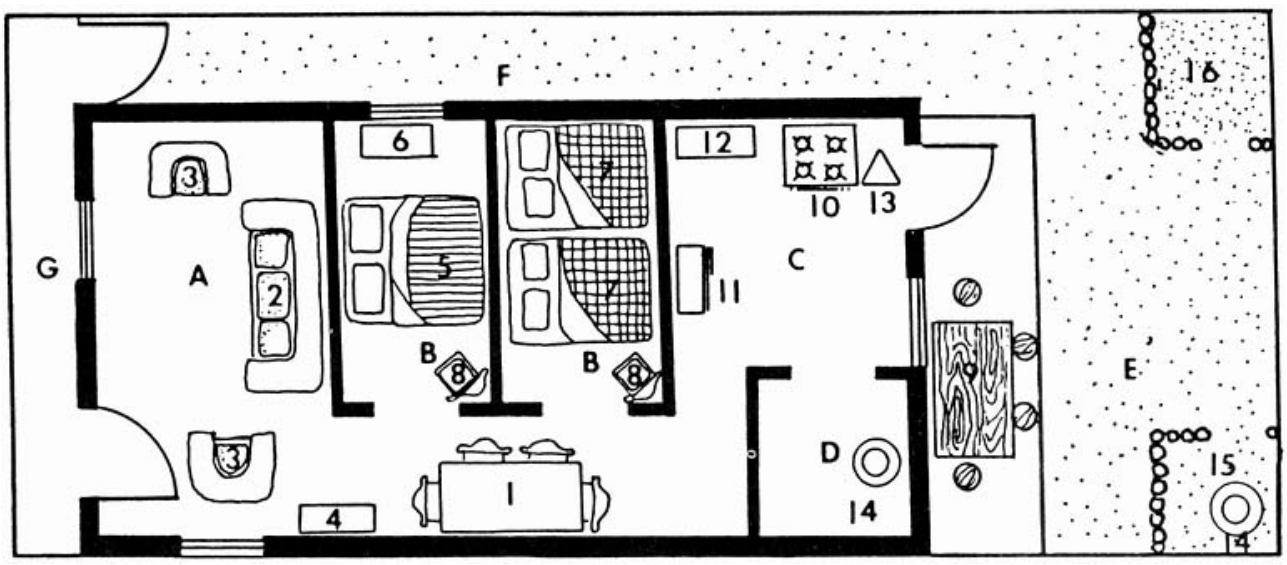

A. Front room

1. tables and chairs

2. couch

3. armchair

4. cabinet

B. Bedroom

5. conjugal bed

6. wardrobe
7. children's bed

8. chair

C. Kitchen and veranda

9. kitchen table and stools

10. gas stove

11. refrigerator

12. cupboard

13. storage rack
D. Pantry

14. metal basin

E. Backyard

15. bathing area

16. open outdoor latrine

F. Side passageway

G. Sidewalk

Figure 2

Floor plan of a typical house in Camurim. 


\section{Kitchen}

The kitchen is the interactional center of the household. When the kitchen becomes too small because of the purchase of a gas stove or refrigerator, a veranda is added that stands in open connection to the backyard. The veranda has a simple lean-to roof under which the large wooden kitchen table and some small stools are placed. The family spends most of its time together at the veranda.

In the kitchen or at the veranda, household and domestic relations are realized. Canoe fishermen state that fishing becomes visible in the kitchen. Due to their short fishing trips, they spend much time at home and are confronted daily with the needs of the household. Quarrels have to be solved and a low média cannot be ignored because of the negative consequences for the emotional and interactional well-being of the family members. Still, even conflict contributes to the maintenance of domestic practice. The domestic world is reproduced when the family eats, cooks, argues, jokes, fights, plays, and gossips together (Berger and Kellner 1964). Without this interaction the household would become an emotionally and socially narrow association of individuals with affinal and consanguineal ties who only act in terms of minimal, contractual obligations.

It is exactly this difference in the quality of the social and emotional association of the family members in the kitchen that differentiates the boat fishing household from the canoe fishing household (for a similar contrast, see Thompson 1985; Thompson, Wailey, and Lummis 1983:175-181). The boat fishermen spend much time away at sea, and when ashore they are most often found in one of the many bars of Camurim. Even though many maintain their families above subsistence level-which can be interpreted as an expression of consideration-their frequent absence does not give them much time and opportunity to express their affection and give interactional substance to their domestic obligations (Tunstall 1962:160-165; Whitaker 1982). Domestic conflicts are seldom dealt with directly because the boat fishermen often leave for sea before the differences can be made up. The conjugal relations of boat fishermen are much more contractual and less affectionate than those of canoe fishermen. The economic dimension of domestic life is much more pronounced in boat fishing households because of the extraneous demands of the public sphere on the limited earnings.

The relation between the kitchen and the economy is especially apparent in the households of boat fishermen who are in perpetual debt to boat owners because their poor catches fail to compensate for their share of the boat's running costs. These fishermen have lost effective control over the material reproduction of the household as the credit advance, given to cover domestic expenses when the men are away at sea, is handed directly to their wives. Domestic and economic power has passed from the men to the women (Grys 1988). The separation between household and economy has broken down because the survival of the family no longer depends on the economic effort of the indebted fishermen but on their membership in a production unit that automatically entitles them to a continuous yet meager flow of credit.

\section{Front Room}

The social context of the front room resembles that of the public domain in which men manipulate social relationships with community members. Canoe fishermen pride themselves on being able to provide entertainment to their colleagues with a television set or a record player. Still, these luxury items do not serve primarily as publicly oriented status symbols but are bought to raise the domestic quality of life. They buy domestic appliances to relieve the heavy domestic chores of their wives, and strive to improve the family's diet with the regular purchase of meat and poultry. Social prestige is more a spin-off from the domestic quality and standard of living than its goal because a canoe fisherman's public reputation comes from receiving the community into his well-provided home rather than from competing for it outside.

Boat fishermen also purchase luxury goods, mainly as tokens of their conjugal responsibility, but their wives have taken over the front room as their public space for the visits 
of friends and relatives. The men consider the front room a showcase for their economic success, but they seldom receive colleagues at home because they cultivate their social contacts in the street. Boat fishermen have to choose between satisfying both their wives' domestic demands and their own public needs. Clothing and food are affected most. Luxury items are usually acquired after a fortuitous catch, but the weekly household budget leaves little leeway to buy meat or pay installments on a piece of clothing. Boat fishermen come close to regarding the household as a contractual liability whose needs must be met morally but whose demands compete with their career interests in the public domain (Robben 1988b).

Ambitious boat fishermen spend substantial portions of their income on brothel visits and alcohol expenses to cultivate a social network of influential friends and patrons. The two brothels of Camurim have a restricted clientele, the core of which consists of a group of boat owners. Even a productive fisherman who has earned the trust and friendship of a boat owner can only attend upon invitation by the group. He is aware that his presence in these brothels and especially the conspicuous consumption of alcohol are essential steps toward capital ownership. Adulterous affairs and drinking are shows of masculinity (McClelland 1984), and the willingness to spend substantial sums of money demonstrates such self-confidence in one's productive capacity that it might earn a fisherman the privilege of accompanying a boat owner on his next get-together with the wealthy elite of Camurim. It is at these exclusive social gatherings that the boat fisherman might finally persuade a landowner to provide the collateral to a bank loan for the purchase of a small fishing vessel.

\section{Bedroom}

The frequent brothel visits of the boat fishermen seem to be in blatant conflict with the marital trust associated with the bedroom. The sharing of the conjugal bed is the most crucial aspect of the marital relationship, the ultimate obligation of husband and wife. A fisherman may beat his wife and children, neglect their welfare, and fail to buy them food, but the community only considers the household as dissolved when husband and wife no longer sleep together. Before entering into a discussion of the way the boat fisherman and his wife deal with adultery and loyalty, a further elaboration of the bedroom itself is in order.

The parents occupy the bedroom closest to the street. They sleep in a double bed with the foot always away from the street and preferably away from the room's doorway. Beds pointing toward the street are associated with death because a deceased person leaves the house feet first. Since the bedroom is associated with life, with procreation and reproduction, a sleeping position that resembles a corpse might incur an untimely death.

The bedroom of the children is spatially protected by the kitchen and the parental bedroom from the harmful influences of the street. The parental bedroom has a window in most houses but the children's bedroom is usually windowless. Windows make the sleeping place vulnerable to undesirable intrusion and undermine the parental control over the children at night. Boys will invariably sleep in the front room when the children reach puberty, while the girls remain in the bedroom. Parents are much more concerned about their daughters' chastity than about the nocturnal escapades of their sons.

Situated spatially in the heart of the house, the parental bedroom, with its association with procreation and intimacy, is also the social domain in the home most sensitive to any violation. Loyalty and sexual interest are vows consecrated at marriage. Adultery is therefore a serious betrayal of marital trust and is especially painful because of the symbolic and spatial isolation of the house from the street. With adultery enters the bad influence of the street that embitters the sanctity of the house and damages the honor of its inhabitants.

Marital infidelity by canoe fishermen is rather uncommon because of their great emphasis on the domestic world, and simply because their daily presence at home makes it difficult to hide illicit affairs from their wives. They sometimes have brief flings, especially 
with female tourists in the summer months, but more stable affairs would imply a drain on the household's limited financial resources that would not go by unnoticed.

Adultery among boat fishermen is far more complicated than among canoe fishermen because extramarital affairs and visits to prostitutes are not just manifestations of physical attraction but are both a means of acquiring social prestige and public proofs of masculinity. Marriage is an important indicator of masculinity because it demonstrates that the married man has the capacity to produce children and maintain a household, has strong sexual needs, and can control his wife in a dependency relation in which he makes all major decisions. Boat fishermen, who spend only two or three long weekends per month ashore, cannot make any convincing claims to masculinity in terms of the general tenets of gender ideology, especially with respect to sexuality and domestic power. The prolonged stay at sea provokes jokes about homosexuality aboard ship and raises the serious suspicion of marital infidelity at home. For these reasons, the boat fishermen affirm their masculinity in local brothels. We may be cuckolds, so they argue, but the cause lies in the nature of fishing, not in our virility.

The penetration of the bedroom by the public domain is even more dramatic in the households of indebted boat fishermen. Strapped for money by the meager trickle of credit, some wives have turned to extramarital affairs with boat owners and storekeepers as a source of livelihood in a community with few job opportunities for women (Kottak 1983:263-270). This desperate move to sustain the family completes the marginalization of the indebted boat fishermen in the home. Already financially unable to provide for the household, buy the usual status symbols for the front room, and invite people into the poor home, their control of the bedroom is also assailed. Their wives do not feel sexually obligated to them, and may even carry their secret lover's child, thus isolating the indebted boat fishermen entirely from the social, material, and biological reproduction of the family.

In this section I have demonstrated that the spatial habitus of the house brings the domestic practices to the attention of the fishermen. The sheer existence of the rooms of the house, the social functions allotted to them in Brazilian culture, and their importance in childhood and socialization create a need for their embodiment in social interaction, exactly because the spatial structure has focused the orientation of domestic practice on the social activities described above. Yet this spatial structure does not determine the quality of domestic practice. The hegemonic parameters of practice set by the habitus of space allow ample leeway for variation. Furthermore, domestic practice does not stand in isolation of other social practices. How the canoe fishermen and boat fishermen of Camurim give interactional substance to domestic space is influenced by their involvement in other domains of society.

\section{Conclusion}

In this article I set myself the task of analyzing the relation between space and interaction. I have shown that in the Brazilian fishing town of Camurim there is a correspondence between the sociospatial divisions and social relationships of the community and the house. In the eyes of the canoe fishermen and boat fishermen of Camurim, the sea, the house, and the street define spatially the economic, domestic, and public domains of society. Material demarcations, transitional spaces, and social trajectories reinforce the boundaries of the sociospatial organizations of house and society. The three societal domains are characterized by contractual, affective, and voluntary relationships that have obligation, consideration, and média, respectively, as their predominant interactional quality. These same qualities appear in a modified form in the house. The kitchen, the bedrooms, and the front room represent domestically the economy, the home, and the public arena, with their analogic types of contractual, affective, and voluntary relations. In all three sociospatial areas of the house there is a marked difference between the domestic practices of the canoe fishermen and the boat fishermen. Boat fishermen are more 
casually involved in the domestic world, while the economic and public domains are far more central in their lives than among canoe fishermen, who dedicate considerably more time and effort to the household.

This article has also shown that it may not always be possible to maintain the boundaries of the domains of society. The social demands of the public domain may compete with the needs of the family. Ambitious boat fishermen spend much time away from home in barrooms and brothels, and may become emotionally and socially distant from their wives and children. At the other end of the social scale, the domestic autonomy of destitute households may be undermined by economic dependence. Indebted boat fishermen have surrendered the maintenance of the household to the capital owner, and have at the same time made their wives vulnerable to dishonest proposals. This blurring of societal domains damages the family's reputation and is felt as socially degrading exactly because of the existence of physical, social, and symbolic barriers. These transgressions challenge the hegemony of the domestic habitus, and may profoundly affect the family's interpretation of their social interaction at home.

It is no mere coincidence that our word "habit," the French habitude, the German Gewohnheit, and the Portuguese and Spanish hábito stand for routine practices and also refer implicitly to the activity and practice of living or dwelling in the house, to inhabit, habiter, wohnen, habitar: "Building as dwelling, that is, as being on the earth, . . . remains for man's everyday experience that which is from the outset 'habitual'-we inhabit it" (Heidegger 1971:147). A child acquires its first social routines and a conception of the social and spatial world within the confines of a house or dwelling. Its motorical, spatial, social, and intellectual habitability is developed through interaction with its most immediate environment (Piaget 1950:319-339). People's cultural being is created via the sociospatial surroundings in which they grow up: "Man's being-in-the-world is structured, and the structure is kept and visualized by means of architecture" (Norberg-Schulz 1985:29). The house is not just a place to rest one's head, or a safe haven within which to withdraw from society: it shapes people's cultural being and the way they relate to one another outside the home. The sociospatial habitus of the house is taken out into the world, which will then come to bear its imprint because "all really inhabited space bears the essence of the notion of home" (Bachelard 1969:5).

However, even though the house and its architectural structure are a formidable force in the constitution of cultural beings, it has to be appropriated incessantly in social practice to give it a meaning beyond that of a material remnant of past lives. People have to dwell in a house in order to reproduce the habitus objectified by it. How they dwell is influenced by their early childhood socialization, the architectural structure of their present living quarters, and the nature of their activities and social interaction outside the domestic world. House and society are not only produced and reproduced in domestic and societal practices through a process of structuration, but they also continually generate and regenerate one another in a structurating dynamic. Socioeconomic and cultural changes - such as the emulation of upper-class architectural innovations in Camurim by absentee boat owners, or the growing importance of the nuclear family in 18th-century Europe which led to a functional reconstruction of domestic space-may prompt new designs of the house. A new spatial habitus will, in turn, produce and reinforce new domestic practices and suggest social ways that will eventually be taken for granted as culturally proper and self-evident. Yet this hegemony will be ruptured once again in the everflowing becoming of being through dwelling.

Acknowledgments. This article is based on research conducted in 1982-83 and funded by the National Science Foundation (Grant BNS 8200732). Continued support from the Michigan Society of Fellows has allowed me to write this article. I thank Claudia Bernardi for drawing the illustrations, and Paul Dresch, Ric Northrup, Moshira El Rafey, John Watanabe, and editor Richard Stoffle together with four anonymous reviewers for their thoughtful comments. Special thanks to Rachael Cohen for word processing and proofreading the manuscript. 


\section{References Cited}

Abu-Lughod, Lila

1986 Veiled Sentiments: Honor and Poetry in a Bedouin Society. Berkeley: University of California Press.

Altman, Irwin, and Anne $M$. Vinsel

1977 Personal Space: An Analysis of E. T. Hall's Proxemics Frameworks. In Human Behavior and Environment, Vol. 2: Advances in Theory and Research. Irwin Altman and Joachim F. Wohlwill, eds. Pp. 181-259. New York: Plenum Press.

Antoun, Richard

1968 On the Modesty of Women in Arab Muslim Villages: A Study in the Accommodation of Traditions. American Anthropologist 70:671-697.

Arendt, Hannah

1958 The Human Condition. Chicago: University of Chicago Press.

Ariès, Philippe

1962 Centuries of Childhood: A Social History of Family Life. Robert Baldick, transl. New York: Alfred A. Knopf.

Aubert, Vihelm

1965 A Total Institution: The Ship. In The Hidden Society. V. Aubert, ed. Pp. 236-258. Totowa, NJ: Bedminster Press.

Bachelard, Gaston

1969 The Poetics of Space. Maria Jolas, transl. Boston: Beacon Press.

Barnes, R. H.

1985 Hierarchy without Caste. In Contexts and Levels: Anthropological Essays on Hierarchy. R. H. Barnes, Daniel de Coppet, and R. J. Parkin, eds. Pp. 8-20. Oxford: JASO.

Benn, Stanley I., and Gerald F. Gaus

1983 The Public and the Private: Concepts and Action. In Public and Private in Social Life. Stanley I. Benn and Gerald F. Gaus, eds. Pp. 3-27. London: Croom Helm.

Berger, Peter, and Hansfried Kellner

1964 Marriage and the Construction of Reality. Diogenes 46:1-24.

Bourdieu, Pierre

1973 The Berber House. In Rules and Meanings. Mary Douglas, ed. Pp. 98-110. Harmondsworth, England: Penguin.

1977 Outline of a Theory of Practice. Richard Nice, transl. Cambridge: Cambridge University Press.

1984 Distinction: A Social Critique of the Judgement of Taste. Richard Nice, transl. Cambridge, MA: Harvard University Press.

Brown, Barbara

1987 Territoriality. In Handbook of Environmental Psychology, Vol. 1: Daniel Stokes and Irwin Altman, eds. Pp. 505-531. New York: John Wiley.

Carlstein, Tommy

1982 Time Resources, Society and Ecology: On the Capacity for Human Interaction in Space and Time. Vol. 1: Preindustrial Societies. London: George Allen \& Unwin.

Cascudo, Luís da Câmara 1954 Dicionário do Folclore Brasileiro. Rio de Janeiro: Ministério da Educação e Cultura.

Certeau, Michel de 1984 The Practice of Everyday Life. Steven Rendall, transl. Berkeley: University of California Press.

Cooper, Clare

1974 The House as Symbol of the Self. In Designing For Human Behavior: Architecture and the Behavioral Sciences. Jon Lang, Charles Burnette, Walter Moleski, and David Vachon, eds. Pp. 130-146. Stroudsburg, PA: Dowden, Hutchinson \& Ross.

Csikszentmihalyi, Mihaly, and Eugene Rochberg-Halton

1981 The Meaning of Things: Domestic Symbols and the Self. Cambridge: Cambridge University Press.

Cunningham, Clark E.

1973 Order in the Atoni House. In Right and Left: Essays on Dual Symbolic Classification. Rodney Needham, ed. Pp. 204-238. Chicago: University of Chicago Press. 
DaMatta, Roberto

1981 Carnavais, Malandros e Heróis: Para uma Sociologia do Dilema Brasileiro. 3rd edition. Rio de Janeiro: Zahar Editores.

1987 A Casa e a Rua: Espaço, Cidadania, Mulher e Morte no Brasil. Rio de Janeiro: Editora Guanabara S.A.

Drummond, Didier

1981 Architectes des Favelas. Paris: Bordas.

Dumont, Louis

1979 The Anthropological Community and Anthropology. Social Science Information 18(6):785-817.

Elias, Norbert

1978 The Civilizing Process, Vol. 1: The Development of Manners. Edmund Jephcott, transl. New York: Urizen Books.

Ellen, Roy

1988 Persistence and Change in the Relationship between Anthropology and Human Geography. Progress in Human Geography 12(2):229-262.

Filho, Adonias

1976 Sul da Bahia: Chāo de Cacau. Rio de Janeiro: Editora Civilização Brasiliera S.A.

Foucault, Michel

1977 Discipline and Punish: The Birth of the Prison. Alan Sheridan, transl. New York: Pantheon Books.

1978 The History of Sexuality, Vol. 1: An Introduction. Robert Hurley, transl. New York: Pantheon Books.

Freyre, Gilberto

1937 Mucambos do Nordeste. Rio de Janeiro: Ministério da Educação e Saude.

1961 Sobrados e Mucambos, Vol. 1: Decadência do Patriarcado Rural e Desenvolvimento do Urbano. 3rd edition. Rio de Janeiro: Livraria José Olympio Editora.

1963[1936] The Mansions and the Shanties: The Making of Modern Brazil. Harriet de Onís, transl. New York: Alfred A. Knopf.

Garcez, Angelina Nobre Rolim, and Antonio Fernando G. de Freitas

1979 Bahia Cacaueira: Um Estudo de História Recente. Salvador: Centro Editorial e Didático da Universidade Federal da Bahia.

Giddens, Anthony

1979 Central Problems in Social Theory: Action, Structure and Contradiction in Social Analysis. London: Macmillan.

1984 The Constitution of Society: Outline of the Theory of Structuration. Cambridge: Polity Press.

1985 Time, Space and Regionalisation. In Social Relations and Spatial Structures. Derek Gregory and John Urry, eds. Pp. 265-295. London: Macmillan.

Gilmore, David

1977 The Social Organization of Space: Class, Cognition, and Residence in a Spanish Town. American Ethnologist 4:437-451.

Glassie, Henry

1975 Folk Housing in Middle Virginia: A Structural Analysis of Historic Artifacts. Knoxville: University of Tennessee Press.

Gramsci, Antonio

1971 Selections from the Prison Notebooks. Quintin Hoare and Geoffrey Nowell Smith, transl. New York: International Publishers.

Grys, Mary Schweitzer de

1988 Does Absence Make the Heart Grow Fonder or only the Influence Stronger? Women in a Peruvian Fishing Village. In To Work and to Weep: Women in Fishing Economies. Jane Nadel-Klein and Dona Lee Davis, eds. Pp. 91-105. St. John's, Newfoundland: Institute of Social and Economic Research, Memorial University of Newfoundland.

Hall, Edward T.

1969 The Hidden Dimension. Garden City, NY: Doubleday.

1974 Handbook for Proxemic Research. Washington, DC: Society for the Anthropology of Visual Communication.

Heidegger, Martin

1962 Being and Time. John Macquarrie and Edward Robinson, transl. New York: Harper \& Row. 
1971 Building Dwelling Thinking. In Poetry, Language, Thought. Albert Hofstadter, transl. Pp. 145-161. New York: Harper \& Row.

1982 The Basic Problems of Phenomenology. Albert Hofstadter, transl. Bloomington: Indiana University Press.

Johnson, Twig

1979 Work Together, Eat Together: Conflict and Conflict Management in a Portuguese Fishing Village. In North Atlantic Maritime Cultures: Anthropological Essays on Changing Adaptations. Raoul Andersen, ed. Pp. 241-252. The Hague: Mouton.

Kent, Susan

1984 Analyzing Activity Areas: An Ethnoarchaeological Study of the Use of Space. Albuquerque: University of New Mexico Press.

Korosec-Serfaty, Perla

1985 Experience and Use of the Dwelling. In Human Behavior and Environment: Advances in Theory and Research, Vol. 8: Home Environments. Irwin Altman and Carol M. Werner, eds. Pp. 65-86. New York: Plenum Press.

Kottak, Conrad Phillip

1983 Assault on Paradise: Social Change in a Brazilian Village. New York: Random House.

Laclau, Ernesto, and Chantal Mouffe

1985 Hegemony and Socialist Strategy: Towards a Radical Democratic Politics. London: Verso Press.

Mårtensson, Solveig

1979 On the Formation of Biographies in Space-Time Environments. Lund, Sweden: Lund Studies in Geography, Series B No. 47.

McClelland, David C.

1984 Drinking as a Response to Power Needs in Men. In Motives, Personality, and Society:

Selected Papers. D. C. McClelland, ed. Pp. 327-342. New York: Praeger.

Moore, Barrington, Jr.

1984 Privacy: Studies in Social and Cultural History. Armonk, NY: M. E. Sharpe.

Nelson, Cynthia

1974 Public and Private Politics: Women in the Middle Eastern World. American Ethnologist $1: 551-563$.

Nolan, B.

1976 Seamen, Drink and Social Structure. Maritime Policy and Management 4:77-88.

Norberg-Schulz, Christian

1971 Existence, Space and Architecture. London: Studio Vista Limited.

1985 The Concept of Dwelling: On the Way to Figurative Architecture. New York: Rizzoli International.

1988 Architecture: Meaning and Place. Selected Essays. New York: Rizzoli International.

Oliver, Paul

1987 Dwellings: The House across the World. Austin: University of Texas Press.

Ortner, Sherry B.

1984 Theory in Anthropology since the Sixties. Comparative Studies in Society and History 26(1):126-166.

Patterson, Arthur H.

1974 Unobtrusive Measures: Their Nature and Utility for Architects. In Designing for Human Behavior: Architecture and the Behavioral Sciences. Jon Lang, Charles Burnette, Walter Moleski, and David Vachon, eds. Pp. 261-273. Stroudsburg, PA: Dowden, Hutchinson \& Ross.

Peristiany, J. G., ed.

1965 Honor and Shame: The Values of Mediterranean Society. London: Weidenfeld and Nicolson.

Piaget, Jean

1950 La construction du réel chez l'enfant. Neuchâtel: Delachaux et Niestlé S.A.

Pierson, Donald

1951 Cruz das Almas: A Brazilian Village. Washington, DC: Smithsonian Institution.

Polanyi, Michael

1958 Personal Knowledge: Towards a Post-Critical Philosophy. London: Routledge \& Kegan Paul. 
Pratt, Gerry

1981 The House as an Expression of Social Worlds. In Housing and Identity: Cross-Cultural Perspectives. James S. Duncan, ed. Pp. 135-180. London: Croom Helm.

Pred, Allan

1981 Social Reproduction and the Time-Geography of Everyday Life. Geografiska Annaler $63 \mathrm{~B}(1): 5-22$.

Ranum, Orest

1986 Les refuges de l'intimité. In Histoire de la vie privée, Vol. 3: De la Renaissance aux Lumières. Philippe Ariès and Georges Duby, eds. Pp. 211-265. Paris: Editions du Seuil.

Rapoport, Amos

1969 House Form and Culture. Englewood Cliffs, NJ: Prentice-Hall.

1982 The Meaning of the Built Environment: A Nonverbal Communication Approach. Beverly Hills: Sage Publications.

Revista Trimensal do Instituto Geographico e Historico da Bahia

1896 Creação da Villa do Prado. Revista Trimensal do Instituto Geographico e Historico da Bahia 3(10):533-550.

Richardson Miles

1982 Being-in-the-Market versus Being-in-the-Plaza: Material Culture and the Construction of Social Reality in Spanish America. American Ethnologist 9:421-436.

Robben, Antonius G. G. M.

1988a The Play of Power: Paradoxes of Brazilian Politics and Soccer. In Social Change in Contemporary Brazil: Politics, Class and Culture in a Decade of Transition. Geert Banck and Kees Koonings, eds. Pp. 135-150. Dordrecht: Foris Publications Holland.

1988b Conflicting Gender Conceptions in a Pluriform Fishing Economy: A Hermeneutic Perspective on Conjugal Relationships in Brazil. In To Work and to Weep: Women in Fishing Economies. Jane Nadel-Klein and Dona Lee Davis, eds. Pp. 106-129. St. John's, Newfoundland: Institute of Social and Economic Research, Memorial University of Newfoundland.

1989 Sons of the Sea Goddess: Economic Practice and Discursive Conflict in Brazil. New York: Columbia University Press.

Romney, A. Kimball, Susan C. Weller, and William H. Batchelder

1986 Culture as Consensus: A Theory of Culture and Informant Accuracy. American Anthropologist $88(2): 313-338$.

Rowntree, Lester

1986 Cultural/Humanistic Geography. Progress in Human Geography 10(4):580-586.

Rybczynski, Witold

1986 Home: A Short History of an Idea. New York: Viking Penguin.

Sahlins, Marshall

1985 Islands of History. Chicago: University of Chicago Press.

Seamon, David

1979 A Geography of the Lifeworld: Movement, Rest and Encounter. London: Croom Helm.

1987 Phenomenology and Environment-Behavior Research. In Advances in Environment, Behavior, and Design, Vol. l. Ervin H. Zube and Gary T. Moore, eds. Pp. 3-27. New York: Plenum Press.

Shapcott, Mary, and Phillip Steadman

1978 Rhythms of Urban Activity. In Timing Space and Spacing Time, Vol. 2: Human Activity and Time Geography. Tommy Carlstein, Don Parkes, and Nigel Thrift, eds. Pp. 49-74. London: Edward Arnold.

Stallybrass, Peter, and Allon White

1986 The Politics and Poetics of Transgression. London: Methuen.

Taylor, Ralph B., and Sidney Brower

1985 Home and Near-Home Territories. In Human Behavior and Environment, Advances in Theory and Research: Vol. 8: Home Environments. Irwin Altman and Carol M. Werner, eds. Pp. 183-212. New York: Plenum Press.

Thompson, Paul

1985 Women in the Fishing: The Roots of Power between the Sexes. Comparative Study of Society and History $27(1): 3-32$.

Thompson, Paul, Tony Wailey, and Trevor Lummis

1983 Living the Fishing. London: Routledge \& Kegan Paul. 


\section{Touraine, Alain}

1977 The Self-Production of Society. Derek Coltman, transl. Chicago: University of Chicago Press.

Tuan, Yi-Fu

1977 Space and Place: The Perspective of Experience. Minneapolis: University of Minnesota Press.

Tunstall, Jeremy

1962 The Fishermen. London: MacGibbon \& Kee.

Van Gennep, Arnold

1960 The Rites of Passage. Monika B. Vizedom and Gabrielle L. Caffee, transl. Chicago: University of Chicago Press.

Watson, O. Michael

1970 Proxemic Behavior: A Cross-Cultural Study. The Hague: Mouton.

Whitaker, Ian

1982 Family Rôles of Distant-Water Trawlermen. Maritime Policy and Management 9:59-72. 